\title{
The Research of Assessing Liquidity and Operational Efficiency
}

\author{
Song $\mathrm{Gao}^{1, \mathrm{a}}$ \\ ${ }^{1}$ School of Business management, Tonghua Normal University, Tonghua 134002, China. \\ adbcy9999@163.com
}

Keywords: invested capital, cash equivalent, capital employ, measure of liquidity.

\begin{abstract}
A firm that can no longer pay its creditors-its bankers and suppliers-is illiquid and technically bankrupt, a situation that no manager wishes to face. Managers must make decisions that do not endanger their firm's liquidity - a term that refers to the firm's ability to meet its recurrent cash obligations toward various creditors. A firm's liquidity is driven by the structure of its balance sheet, namely, by the nature and composition of its assets and the way they are financed. To finance these investments, the firm uses a combination of short-term and long-term sources of funds. One way a firm can manage its balance sheet and en-hance its liquidity is by using the matching strategy. This strategy requires that long-term investments be financed with long-term funds and short-term investments with short-term funds. We show in this chapter that the matching principle helps explain how a firm's liquidity should be measured and how liquidity is affected by manage-rial decisions.
\end{abstract}

\section{The managerial balance sheet}

Recall that the purpose of the firm's balance sheet is to determine the investment made by the firm's owners - its shareholders - in their firm at a specific date. The investment, called owners' equity, is the difference between the firm's assets and li-abilities, where assets are items owned by shareholders, and liabilities are debts owed to creditors, suppliers, employees, and other entities.

For managers of a firm's operating activities, the standard balance sheet may not be the most appropriate tool for assessing their contribution to the firm's finan-cial performance. To illustrate this point, consider trade payables. They are cor-rectly recorded in the balance sheet as a liability because they represent cash owedto suppliers. Most operating managers, however, would consider trade payables an account under their full responsibility, much like trade receivables (cash owed to the firm by its customers) and inventories, both of which are recorded on the asset side of the balance sheet. It makes more managerial sense to associate trade pay-ables with trade receivables and inventories than to combine them with other liabilities — such as short-term borrowings and long-term debt — that are primarily the responsibility of the financial manager.

In the following sections, we show how to restructure the standard balance sheet into the managerial balance sheet, and explain why it is a more appropriate tool to identify the links between managerial decisions and financial performance.

On the left side of the managerial balance sheet, three items are grouped under the heading invested capital. These are cash and cash-equivalent holdings, working capital requirement (WCR) (the difference between the firm's operating assets and its operating liabilities), and net fixed assets:

\section{The three components of a firm's invested capital}

A firm's capital is used to finance investments [1-2] in (1) cash and cash-equivalent as-sets; (2) working capital requirement (WCR); and (3) fixed assets, such as property, plant, and equipment. We begin with a brief review of cash and fixed assets and then analyze WCR in more detail.

\section{Cash and cash equivalent assets}

Firms hold cash and cash-equivalent [3-4] assets (also called liquid assets) for at least two reasons: (1) as a precautionary measure and (2) to build up cash balances for future uses. Some customers may not 
pay the invoices sent to them exactly at the agreed-upon date. In between, the firm may find itself not being able to pay its sup-pliers or pay its employees' salaries on time. To avoid being caught in a cash squeeze, most firms hold cash balances as a precautionary measure, referred to as operating cash. 2 On top of cash balances needed to support operating activities, firms also may hold temporary amounts of cash, or excess cash, for future uses, such as the payment of cash dividends, the repurchase of shares, or the acquisition of new businesses. Also, firms sometimes hold cash because banks require their corporate clients to maintain some compensating balances for services they provide to the firm. We use the generic word cash to refer not only to cash in hand but also to any cash-equivalent assets.

To have access to more cash, some firms, particularly large ones, can negotiate credit lines with their banks. This is an agreement in which the bank, for a fee, ex-tends a specific amount of credit for a short period of time at the discretion of the firm. Information about the agreement is usually found in the notes to the firm's balance sheet.

\section{The two components of a firm's capital employed}

How should the firm's invested capital be financed? Two primary sources of capital are available to firms: (1) the equity capital provided by owners and (2) the debt capital provided by debt holders. Debt can be short term (due to be repaid within one year) or long term (due to be repaid after one year). 3 Thus, a firm's total capital employed can be classified either as equity and debt capital or as long-term financing (equity plus long-term debt) and short-term financing (short-term debt). The first approach distinguishes the nature of the firm's capital employed [5-7] whereas the second distinguishes its duration.

Given these alternative sources of capital, the firm's managers must answer two questions when deciding which strategy should be adopted to fund the firm's investments:

1. What is the best combination of equity capital and debt capital?

2. What proportion of borrowed funds should be in the form of long-term debt and what proportion in the form of short-term debt?

The answer to the first question affects the firm's profitability and financial risk.

\section{The matching strategy}

In deciding how much of the firm's investments should be financed with long-term funds and how much with short-term debt, most firms try to apply the matching strategy. According to this strategy, long-term investments should be financed with long-term funds and short-term investments should be financed with short-term funds. By matching the life of an asset and the duration of its financing source, a firm can minimize the risk of not being able to finance the asset over its entire useful life.

Consider a piece of equipment with a useful life of five years. Its purchase price can be financed either with a five-year loan (a matched financing strategy) or with a one-year renewable loan (a mismatched financing strategy), both at the same interest rate. Which of the two strategies is riskier?

The mismatched strategy is riskier for two reasons. First, the interest rate, and thus the cost of financing the equipment, may change during the following four years. Second, the lender may be unwilling to renew the one-year loan, thus forcing the firm to repay its loan after one year. This situation may require the sale of the equipment and the early termination of the investment. These two types of risk, called financial cost risk and refinancing risk, respectively, are clearly much lower under the matching strategy.

However, matching the maturity structure of the firm's sources of financing with the maturity of its assets is not necessarily the optimal financing strategy for every firm at all times. Some firms, at times, may be willing to carry some financial cost and refinancing risks if they expect short-term interest rates to go down. 5 On the other hand, firms that are more risk averse may choose to carry more long-term funds than necessary under the matching strategy. Appendix 3.1 provides an 
illustration of matched and mismatched financing strategies for firms with growing and seasonal sales.

Some firms can adhere to the matching strategy without entirely financing their WCR with long-term funds. Consider a firm that has growing but seasonal sales. If the firm maintains a constant ratio of WCR to sales over time, then its working capital requirement will display a seasonal growth behavior. Figure 1 illustrates this situation for WCR equal to 25 percent of sales. In this case, WCR has a long-term growth component (called permanent WCR) and a short-term seasonal component (called seasonal WCR). According to the matching strategy, the long-term growth component should be financed with long-term funds and the seasonal component with short-term funds. Applying this funding strategy should reduce both financial cost and refinancing risks.

Fig. 1 WCR is assumed to be set at 25 percent of sales.

\section{A measure of liquidity based on the funding structure of working capital requirement}

For most firms that adopt it, the matching strategy is an objective

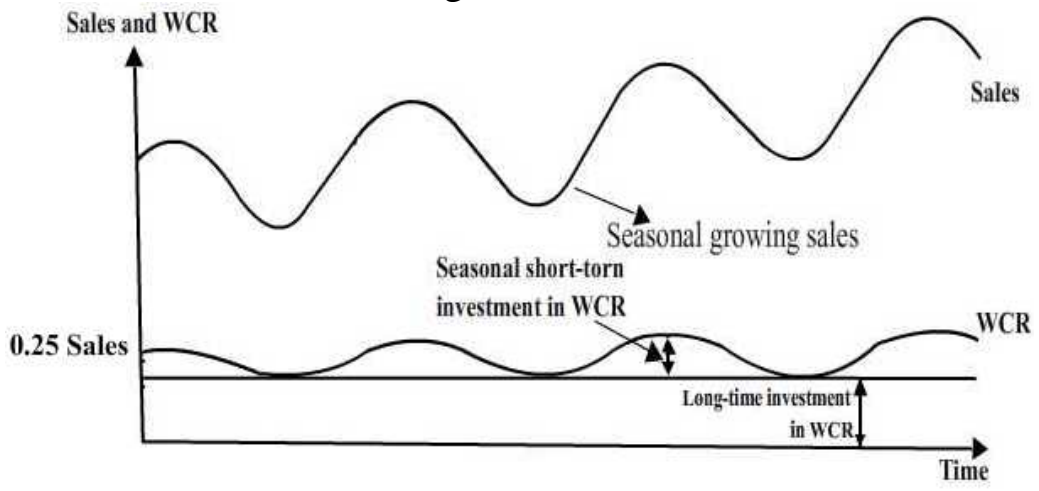
rather than a day-to-day reality. The goal of management is for long-term funds to match the firm's long-term investments (net fixed assets and permanent WCR) and for short-term funds to match the firm's short-term investments (cash, marketable securities, and seasonal working capital requirement [8-9] ) over time. This objective may not beeasily achieved in practice, and at times, the firm may find itself in a mismatched situation in which a significant portion of its permanent working capital is funded with short-term debt. This situation can create a liquidity problem. This section presents a measure of liquidity that managers can use to monitor their firm's liquidity position. The measure is based on the funding structure of WCR-more precisely, on the portion of WCR that is funded with long-term financing.

\section{Improving liquidity through better management of the operating cycle}

Decisions related to the management of long-term financing and net fixed assets are strategic in nature. Long-term financing will increase if the firm (1) issues long-term debt, (2) raises new equity capital (issues new shares), or (3) increases retained earnings by reducing dividend payments. Net fixed assets will decrease if the firm sells property and other fixed assets. Generally, these decisions are infrequent and involve large amounts of cash. They are also prepared well in advance so that the firm's financial manager, who actively participates in this decision-making process, can easily forecast their effect on the firm's liquidity. Decisions affecting the firm's working capital requirement are related to the management of the firm's operating cycle. They determine the amount of receivables, inventories, prepaid expenses, payables, and accrued expenses in the firm's balance sheet. Contrary to strategic decisions, operating decisions are made frequently (a company receives payments from its customers many times a day), they involve relatively small amounts of cash, and, often, they do not directly involve the firm's financial manager. They affect the firm's liquidity continually and are difficult to forecast in the aggregate. Through these operating decisions, a firm's operating managers influence the firm's liquidity. The lower the firm's investment in its operating cycle, the lower its WCR and the higher the firm's liquidity [10]. Furthermore, the lower the frequency of unexpected changes in the firm's WCR, the less volatile the firm's liquidity position and the easier it is to manage. Clearly, control of the amount and fluctuations of a firm's WCR is the key to the sound man agement of the firm's liquidity. 
Controlling WCR requires identifying and understanding the factors that affect its size. Five items make up a firm's WCR: receivables, inventories, prepaid expenses, payables, and accrued expenses. The size of these five items depends on the following three basic factors:

1. The nature of the economic sector in which the firm operates,

2. The degree of efficiency with which the firm manages its operating cycle, and

3. The level and growth of sales

\section{Summary}

A firm's liquidity is driven by the structure of its balance sheet, that is, by the nature and composition of its assets and the way they are financed. Liquidity is easier to analyze if the standard balance sheet is restructured into the managerial balance sheet. The higher that ratio, the higher the proportion of working capital that is financed with long-term funds and the higher the firm's liquidity. The portion of working capital that is not financed with long-term funds is obviously financed with short-term debt. These short-term borrowings in excess of cash are called net short-term financing (NSF). To minimize the effect of both financial cost risk and refinancing risk, most firms should limit the short-term financing of their working capital to its seasonal short-term component while financing the permanent long-term component with long-term funds. This approach to funding is known as the matching strategy. The key to good liquidity management is good management of the firm's working capital cycle; a liquidity crisis is often the symptom of a mismanaged working capital cycle. Broadly speaking, good management of the working capital cycle means two things. First, accounts receivable and inventories, the two major components of working capital, must be held at their minimum levels relative to sales. This will allow the firm to save the cash it would have needed to fund a larger amount of receivables and inventories. Second, because WCR is essentially a long-term investment, a firm's liquidity will rise as higher proportions of its working capital are financed with long-term funds. Finally, the ratio of NLF to WCR is a better indicator of a firm's liquidity position than the traditional benchmarks of net working capital, current ratio, or quick ratio. These last two ratios may be good indicators of a firm's ability to rapidly repay its current liabilities with the cash raised from the sale of its current assets, but they are not reliable measures of a firm's capacity to meet its cash obligations on a recurrent basis.

\section{References}

[1] Günter Bamberg, Gregor Dorfleitner, On a neglected aspect of portfolio choice: the role of the invested capital, Review of Managerial Science, 7 (2013) 85-98.

[2] Anonymous, American Capital Strategies Ltd.; American Capital Invests in NextPoint Networks, Computers, Networks \& Communications, (2008).

[3] Richard J. Sweeney, Equivalent valuations in cash flow and accounting models, Review of Quantitative Finance and Accounting, 42 (2014) 29-49.

[4] Byung-cheol Kim, Euysup Shim, KennethF. Reinschmidt, Probability Distribution of the Project Payback Period Using the Equivalent Cash Flow Decomposition, The Engineering Economist, 58 (2013) 112-136.

[5] Ove Mørch, Kjetil Fagerholt, Giovanni Pantuso, Jørgen Rakke, Maximizing the rate of return on the capital employed in shipping capacity renewal, Omega (2016).

[6] JASMINE LORENZINI, MARCO GIUGNI, Employment Status, Social Capital, and Political Participation: A Comparison of Unemployed and Employed Youth in Geneva, Swiss Political Science Review, 18 (2012) 332-351.

[7] Lina Aldén, Mats Hammarstedt, Discrimination in the Credit Market? Access to Financial Capital among Self - employed Immigrants, Kyklos 69 (2016).

[8] Edward I. Altman, Gabriele Sabato, Effects of the New Basel Capital Accord on Bank Capital Requirements for SMEs, Journal of Financial Services Research, 28 (2005) 15-42. 
[9] Nino Savelli, Gian Paolo Clemente, A Risk-Theory Model to Assess the Capital Requirement for Mortality and Longevity Risk, Journal of Interdisciplinary Mathematics, 16 (2013) 397-429.

[10] Byeongyong Paul Choi, Jin Park, Chia-Ling Ho, Liquidity creation or de-creation: evidence from US property and liability insurance industry, Managerial Finance, 39 (2013) 938-962. 